\title{
IMPLEMENTASI PENDIDIKAN KARAKTER PADA ANAK USIA DINI (Penelitian di Raudhatul Atfaal Nurul Ikhlas Depok)
}

\author{
Isep Djuanda ${ }^{1}$ \\ STAI Al Hamidyah Jakarta \\ Email: isep_dj@yahoo.com \\ Hikmah Maryliana ${ }^{2}$ \\ STAI Al Hamidyah Jakarta \\ Email: hikmahmaryliana@gmail.com
}

\begin{abstract}
This study aimed to perceive the implementation of character education for young learners in RA Nurul Ikhlas and discover the supporting factors and obstacles in implementing the program.

Conducted using a qualitative method, the study resulted in the findings of definitions, concepts, characteristics, and phenomena on the implementation of character education for young learners in RA Nurul Ikhlas. The data was collected by observation, interview, and document analysis. The data analysis was conducted by applying Miles and Hubermen' theory, which consisted of data reduction activity, data presentation, and conclusion drawing.

The findings showed that: 1) Character education implementation in RA Nurul Ikhlas was conducted by scheduled activities, habits and merits, and learning by playing approach. Character education curriculum based on 9 character-pillars with center and circle learning model as well as various methods and evaluation: 2) the supporting factors for implementing character education are lesson plans integrated with character values, teachers' competences, and school support. Meanwhile, the obstacles that hindered the implementation are as follows: a. the harmony between schools and homes in applying characters values are not favorable, b. less-conducive environment, c. uncontrolled or less-educated use of gadget, television, and internet.
\end{abstract}

Key words: Implementation, Character Education, Young Learners 


\begin{abstract}
ABSTRAK
Penelitian dilaksanakan dengan tujuan untuk mengetahui implementasi pendidikan karakter pada anak usia dini di RA Nurul Ikhlas dan mengetahui faktor pendukung dan penghambat dalam mengimplementasikan pendidikan karakter pada anak usia dini di RA Nurul Ikhlas.

Jenis penelitian yang digunakan adalah penelitian kualitatif sehingga diperoleh makna, konsep, karakteristik dan fenomena tentang implementasi pendidikan karakter pada anak usia dini di RA Nurul Ikhlas.Teknik pengumpulan data menggunakan observasi, wawancara dan studi dokumentasi, dengan analisis datanya menggunakan teori Miles dan Hubermen, yang terdiri dari aktifitas reduksi data, penyajian data dan penarikan kesimpulan.

Hasil penelitian menunjukan: 1) Implementasi pendidikan karakter di RA Nurul Ikhlas dilaksanakan melalui melalui kegiatan terprogram, pembiasaan dan keteladanan, dengan pendekatan learning by playing. Kurikulum pendidikan karakter berbasis sembilan pilar karakter dengan model pembelajaran sentra dan lingkaran, serta metode dan evaluasi yang variatif; 2) Faktor yang mendukung implementasi pendidikan karakter, yaitu adanya RPPH yang terintegrasi dengan nilai-nilai karakter, kompetensi guru dan dukungan sekolah. Sedangkan faktor hambatannya adalah keselarasan penguatan nilai-nilai karakter di sekolah dan di rumah yang belum optimal, b. Lingkungan yang kurang kondusif c. Penggunaan gadget, televisi dan internet yang tidak terkontrol atau tanpa edukasi yang optimal.
\end{abstract}

Kata Kunci: Implementasi, Pendidikan Karakter, Anak Usia Dini 


\section{PENDAHULUAN}

\section{Latar Belakang Masalah}

Pendidikan merupakan usaha yang dirancang untuk mengembangkan potensi manusia sehingga memiliki kecerdasan spritual, kecerdasan emosional, kecerdasan sosial serta kemampuan berpikir kritis dan kreatif, yang pada akhirnya bermuara pada pembentukan generasi berakhlaq mulia dan berkarakter bangsa.

Pembentukan generasi berakhlaq mulia dan berkarakter bangsa dibutuhkan di tengah situasi kehidupan masyarakat dimana mulai lunturnya budaya malu, mengambil/memiliki sesuatu yang bukan haknya, ketidakjujuran, kehidupan yang hedonis, lunturnya nilai-nilai nasionalisme, dekadensi moral, kenakalan remaja dan masalah-masalah sosial lainnya. Itu semua berpangkal pada belum efektifnya pelaksanaan pendidikan karakter.

Melihat berbagai permasalahan yang ada pada bangsa ini, pendidikan karakter menjadi bagian penting dalam menanamkan nilai-nilai ke-Islaman dan ke-Indonesian bagi generasi muda yang dimulai sejak usia dini. Penanaman nilainilai tersebut dapat dilakukan dengan membentuk karakter positif sejak usia dini sehingga akan tumbuh menjadi generasi yang religius, unggul, maju, dan terpercaya.

Pendidikan karakter pada anak usia dini perlu dilakukan secara terusmenerus dan berkesinambungan, melalui kegiatan pembiasaan, pembelajaran dan keteladanan. Selain itu, diperlukan kerjasama yang selaras antara keluarga, sekolah dan masyarakat dalam mengembangkan pendidikan karakter pada anak usia dini.

Keluarga adalah lingkungan pertama dan utama dimana anak dikenalkan dan dibiasakan nilai-nilai agama dan karakter yang baik. Untuk itu, orang tua bisa menjadi contoh dan teladan. Lingkungan sekolah juga memiliki peran yang besar, guru tidak hanya menyampaikan materi tetapi juga harus menjadi pendidik karakter, moral dan budaya yang baik bagi anak didiknya. Begitupun lingkungan masyarakat yang memiliki pengaruh dalam memberikan stimulus dalam memberikan contoh, keteladanan serta karakter yang baik.

Berdasarkan pemikiran yang telah dipaparkan di atas perlu dikembangkan desain implementasi pendidikan karakter pada anak usia dini. Untuk mengetahui bagaimana mengimplementasikan pendidikan karakter pada anak usia dini, maka dilakukan penelitian di Raudhatul Atfaal (RA) Nurul Ikhlas Depok dengan harapan pendidikan karakter yang diberikan sejak dini dapat menjadi pondasi kuat bagi anak untuk hidup pada masanya, dengan judul "Implementasi Pendidikan Karakter Pada Anak Usia Dini di Raudhatul Atfaal Nurul Ikhlas Depok".

\section{Perumusan Masalah}

Rumusan masalah dalam penelitian ini adalah sebagai berikut :

a. Bagaimana implementasi pendidikan karakter pada anak usia dini di RA Nurul Ikhlas?

b. Apa saja faktor pendukung dan penghambat dalam mengimplementasikan pendidikan karakter pada anak usia dini di RA Nurul Ikhlas?

\section{Tujuan Penelitian}

Tujuan yang dicapai dalam penelitian ini adalah :

a. Untuk mengetahui bagaimana implementasi pendidikan karakter pada anak usia dini di RA Nurul Ikhlas? 
b. Untuk mengetahui faktor pendukung dan penghambat dalam mengimplementasikan pendidikan karakter pada anak usia dini di RA Nurul Ikhlas?

\section{PEMBAHASAN}

\section{Pengertian pendidikan karakter}

Kata pendidikan berasal dari kata didik dan didikan. Didik berarti memelihara dan memberi latihan mengenai akhlak dan kecerdasan pikiran. Pendidikan secara bahasa dapat diartikan sebagai proses pengubahan sikap dan tata laku seseorang atau sekelompok orang dalam usaha mendewasakan manusia melalui upaya pengajaran, pelatihan, dan pembimbingan. ${ }^{1}$

Sementara kata karakter sebagaimana dijelaskan dalam kamus besar bahasa Indonesia, karakter merupakan sifat-sifat kejiwaan, akhlak atau budi pekerti. ${ }^{2}$ Karakter juga dipahami sebagai seperangkat ciri perilaku yang melekat pada diri seseorang yang menggambarkan tentang keberadaan dirinya kepada orang lain. Penggambaran itu tercermin ketika seseorang melakukan berbagai aktivitas apakah secara efektif melaksanakan dengan jujur atau sebaliknya, apakah dapat mematuhi hukum yang berlaku atau tidak. ${ }^{3}$

Menurut Winnie, karakter memiliki dua pengertian, yaitu: Pertama, menunjukkan bagaimana seseorang bertingkah laku. Kedua, istilah karakter erat kaitannya dengan "personality". Seseorang baru bisa disebut "orang yang berkarakter" (a person of character) apabila tingkah lakunya sesuai dengan kaidah moral. ${ }^{4}$

Lebih jauh, secara teori istilah karakter dikemukakan oleh Thomas Lickona dengan konsep karakter baik (good character) yang merujuk pada konsep yang dikemukakan oleh Aristoteles, "the life of right conduct, right conduct in relation to other persons and in relation to oneself" atau kehidupan berperilaku baik atau penuh kebajikan, yakni berperilaku baik terhadap pihak lain (Tuhan Yang Maha Esa, manusia, dan alam semesta) dan terhadap diri sendiri. ${ }^{5}$

Berdasarkan penjelasan para ahli dapat disimpulkan, karakter adalah perilaku yang mencerminkan kepribadian seseorang dalam berinteraksi dengan orang / pihak lain.

Sementara kata pendidikan karakter sebagaimana dijelaskan Ratna Megawangi pendidikan karakter merupakan suatu usaha untuk mendidik anak usia dini agar dapat mengambil keputusan dengan bijak dan mempraktikkannya dalam kehidupan sehari-hari sehingga mereka dapat memberikan kontribusi yang positif kepada lingkungannya. ${ }^{6}$ Biasanya orang yang berhasil melakukan penyesuain sosial dengan baik mengembangkan sikap sosial yang menyenangkan,

${ }^{1}$ Novan Ardy Wiyani, Dr., Pendidikan Karakter Berbasis Total Quality Management, (Maguwoharjo: Ar-Ruzz Media, 2018) hal.71.

${ }^{2}$ Kokom Komalasari dan Didin Saripudin, Pendidikan Karakter Konsep dan Aplikasi Living Values Education, (Bandung: PT Refika Aditama, 2017), hal.1.

${ }^{3}$ Muhammad Yaumi, Dr.. Pendidikan Karakter: Landasan, Pilar, dan Implementasi, (Jakarta: Prenadamedia Group,2014, hal.120.

${ }^{4}$ Barnawi \& M. Arifin, Strategi \& Kebijakan Pembelajaran Karakter Pendidikan Karakter, (ArRuzz Media, 2012) hal.21

${ }^{5}$ Imas kurniasih S.Pd \& Berlin Sani, Pendidikan karakter: Internalisasi dan Metode Pembelajaran di Sekolah, (Kata Pena,2017)hal. 22

${ }^{6}$ Dharma Kesuma, M.Pd dkk, Pendidikan Karakter:Kajian Teori dan Praktik di Sekolah, (Bandung: PT Remaja Rosdakarya, 2013) hal. 5. 
seperti kesediaan untuk membantu orang lain, meskipun mereka sendiri mengalami kesulitan. ${ }^{7}$

Elkind dan Sweet menyebutkan pendidikan karakter dimaknai sebagai berikut: "character education is the deliberate effort to help people understand, care about, and act upon core ethical values". Pendidikan karakter adalah suatu usaha sengaja untuk membantu orang memahami, peduli dan bertindak menurut nilai-nilai etika. Sementara itu menurut Ramli, pendidikan karakter memiliki esensi dan makna yang sama dengan pendidikan moral dan pendidikan akhlak. ${ }^{8}$ Dalam persepektif ajaran Islam, pendidikan karakter merupakan sebuah upaya sadar dan terencana untuk membentuk, mengarahkan, dan membimbing akhlak peserta didik dalam kehidupan sehari-hari yang sesuai dengan ajaran Islam yang bersumber dari Al-Quran, Hadist dan Ijtihad. ${ }^{9}$

Berdasarkan penjelasan para ahli dapat disimpulkan, pendidikan karakter adalah usaha sadar dan terencana untuk membentuk, mengarahkan, dan membimbing perilaku peserta didik dalam kehidupan sehari-hari yang sesuai dengan nilai-nilai yang dianutnya.

\section{Nilai-Nilai Pendidikan Karakter}

Kementerian Pendidikan Nasional mensosialisasikan 18 nilai pendidikan budaya dan karakter bangsa yang terintegrasi kedalam mata pelajaran, pengembangan diri, dan budaya sekolah. Nilai-nilai tersebut terdiri dari:

a. Religius

Religius merupakan sikap dan perilaku yang patuh dalam melaksanakan ajaran agama yang dianutnya, toleran terhadap pelaksanaan agama lain, dan hidup rukun dengan pemeluk agama lain. Sikap ini dapat diaplikasikan kepada anak usia dini dengan memberikan berbagai kegiatan keagamaan seperti sholat berjamaah, menghafal doa-doa dan datang ke tempat ibadah.

b. Jujur

Jujur merupakan perilaku yang didasarkan pada upaya menjadikan dirinya sebagai orang yang selalu dapat dipercaya dalam perkataan, tindakan dan pekerjaan. Sikap ini dapat diimplementasikan secara efektif kepada anak dengan cara memberi keteladanan secara langsung seperti berkata dan berbuat jujur kepada anak, dengan cara-cara seperti inilah anak dapat mengenal dan memahami kejujuran.

c. Toleransi

Merupakan sebuah sikap yang menghargai atau menghormati perbedaan yang ada pada orang lain, seperti pendapat, agama, suku dan sebagainya. Sikap ini dapat dipraktekkan kepada anak dengan cara melatih anak untuk saling mengasihi tanpa melihat status dan latar belakang seseorang.

d. Disiplin

Merupakan sebuah tindakan yang menunjukan perilaku tertib dan patuh terhadap ketentuan dan peraturan yang ada di lingkungan. Kedisiplinan dapat diajarkan kepada anak dengan cara sederhana namun tegas, sepeti menempatkan sepatu pada tempatnya, berdoa sebelum melakukan pekerjaan apapun.

e. Kerja keras

\footnotetext{
${ }^{7}$ Elizabeth B. Hurlock, Perkembangan Anak, (Jakarta: Erlangga, 2016) cet ke 6 hal.287.

${ }^{8}$ Kementrian Pendidikan Nasional, 2011. Panduan Pelaksanaan Pendidikan Karakter, Pusat Kurikulum dan Perbukuan, h.13

${ }^{9}$ Novan Ardy Wiyani, Pendidikan Karakter Berbasis Total Quality Management, (Maguwoharjo: Ar-Ruzz Media, 2018), hal.74.
} 
Yaitu prilaku yang menunjukan kesungguhan seseorang dalam hal menyelesaikan masalah ataupun meraih keinginannya, tidak bergantung pada orang lain. Sikap ini dapat dibelajarkan kepada anak dengan cara mengajak mengunujungi tempat-tempat atau orang-orang yang sedang melakukan pekerjaan dengan giat, seperti mengajak anak untuk melihat petani yang sedang berladang di sawah, tukang makanan yang sedang menjajakan makanannya dipinggir jalan, dan lain sebagainya.

f. Kreatif

Kreatif adalah berpikir dan melakukan sesuatu untuk menghasilkan cara atau hal baru dari sesuatu yang telah dimiliki. Memberikan kebebasan anak untuk berekspresi sesuai keinginannya merupakan cara mengaplikasikan sifat kreatif kepada anak.

g. Mandiri

Merupakan sikap dan perilaku yang tidak bergantung pada orang lain dalam hal apapun. Sikap ini dapat diajarkan kepada anak dengan memberikan kesempatan kepada anak untuk melakukan berbagai hal sendiri, seperti belajar, makan, membuat minum maupun memakai baju.

h. Demokratis

Merupakan cara berpikir, bersikap, dan bertindak serta menilai hak dan kewajibannya sama dengan orang lain. Anak dapat diajarkan berdemokrasi dengan cara memberikan kesempatan kepada anak untuk menyampaikan pendapatnya.

i. Rasa ingin tahu

Merupakan sikap dan tindakan yang selalu berupaya untuk mengetahui lebih mendalam dan meluas dari sesuatu yang dipelajarinya, dilihat, dan didengar. Salah satu cara mengajarkan anak dalam hal ini ialah dengan cara membiarkan mereka bertanya tentang hal apapun.

j. Semangat kebangsaan

Semangat kebangsaan merupakan cara berpikir, bertindak, dan berwawasan yang menempatkan kepentingan bangsa dan negara di atas kepentingan pribadi dan kelompoknya. Anak dapat diajarkan semangat kebangsaaan dengan cara belajar untuk tidak korupsi dan tertib berlalu lintas.

k. Cinta tanah air

Cinta tanah air atau disebut juga nasionalisme merupakan cara berpikir, bersikap, bertindak yang menunjukan kesetiaan, kepedulian, dan pengharagaan yang tinggi terhadap bahasa, lingkungan fisik, sosial, budaya, ekonomi, dan politik bangsa. Di dalam ajaran Islam terdapat ungkapan hubbul wathan minal iman yang artinya cinta tanah air adalah sebagian dari iman. Pendidikan mengenai cinta tanah air dapat ditanamkan dengan cara mengenalkan kebudayaan-kebudayaan Indonesia, selain itu dapat pula dengan mengajarkan menggunak produk-produk asli Indonesia kepada anak-anak.

1. Menghargai prestasi

Merupakan sikap atau tindakan yang mendorong dirinya untuk menghasilkan sesuatu yang berguna bagi masyarakat, serta mengakui dan menghormati prestasi orang lain. Memberikan pengharagaan terhadap karya anak merupakan cara yang sangat efektif agar anak dapat menghargai suatu prestasi yang dia dapatkan. 
m. Bersahabat / komunikatif

Merupakan sebuah tindakan yang senang berinteraksi dengan orang lain, seperti berbicara, bergaul maupun bekerjasama. Dalam tujuan melatih anakanak bersahabat dengan lingkungannya, dapat dilakukan dengan cara melakukan kegiatan belajar atau bermain secara berkelompok, sebab dengan cara ini dapat menimbulkan rasa persahabatan antar anak yang satu dan lainnya.

n. Cinta damai

Adalah sikap, perkataan, tindakan yang menyebabkan orang lain merasa aman, senang akan kehadiran diri kita. Mengajarkan anak untuk selalu meminta atau memberi maaf kepada orang lain, merupakan cara untuk mengajarkan anak tentang cinta damai.

o. Gemar membaca

Ialah kebiasaan menyediakan waktu untuk membaca berbagai bacaan yang memberikan kebajikan dan menambah wawasan bagi dirinya. Membiasakan anak berinteraksi dengan buku akan memberikan dampak yang baik untuk masa depan anak.

p. Peduli lingkungan

Merupakan sebuah sikap dan tindakan yang selalu berupaya meencegah kerusakan pada lingkungan di sekitar, selain itu memperbaiki lingkungan yang rusak juga merupakan tindakan peduli kepada lingkungan. Membuang sampah pada tempatnya, menanam tumbuh-tumbuhan merupakan salah satu cara untuk mengajarkan anak akan rasa peduli terhadap lingkungan.

q. Peduli sosial

Merupakan sikap dan perilaku yang selalu ingin membantu orang lain yang sedang membutuhkan. Perasaan empati, simpati terhadap orang lain juga merupakan bentuk dari peduli sosial. Dengan mengajak anak ke panti asuhan, terjun membantu korban bencana dapat menimbulkan rasa peduli sosial kepada anak terhadap orang lain.

r. Tanggung Jawab

Tanggung Jawab adalah sikap dan perilaku seseorang untuk melaksanakan tugas dan kewajibannya, yang seharusnya dia lakukan, terhadap diri sendiri, masyarakat, lingkungan, negara maupun Allah SWT. Upaya yang dapat dilakukan dalam menanamkan sikap tanggung jawab adalah dengan mengajak untuk selalu membereskan mainannya setelah dia bermain serta mengembalikan ketempat asalnya, selain itu merapikan tempat tidur juga merupakan upaya untuk mengajarkan anak akan sikap bertanggung jawab.

Pendapat senada disampaikan oleh IHF (Indosnesia Heritage Foundation) yang mengembangkan nilai-nilai pendidikan karakter melalui pendidikan sembilan pilar karakter sejak tahun 2000, yaitu: 1) Cinta Tuhan dan segenap ciptan-Nya (manusia, alam, hewan, tumbuhan); 2) Mandiri, disiplin, dan tanggung jawab (termasuk hidup hemat dan gemar menabung); 3) Jujur, amanah dan berkata bijak; 4) Hormat, santun, dan pendengar yang baik; 5) Dermawan, suka menolong, dan kerja sama; 6) Percaya diri, kreatif, dan patang menyerah; 7) Pemimpin yang baik; 8) Baik dan rendah hati; dan 9) Toleran, cinta damai, dan bersatu. $^{11}$

\footnotetext{
${ }^{10}$ Muhammad Fadhillah dan Lilif Mualifatu Khorida, Pendidikan Karakter Anak Usia Dini, (Maguwoharjo:Ar-Ruzz Media2013), hal.190.

${ }^{11}$ Ratna Megawangi, Pendidikan Karakter Solusi yang Tepat Untuk Membangun Bangsa, (Bogor, Indonesia Heritage Foundation 2016) cet. 5 hal.122
} 


\section{Pendidikan Anak Usia Dini}

\section{Pengertian pendidikan anak Usia Dini}

Dalam Undang-Undang No.20 Tahun 2003 tentang sistem pendidikan nasional disebutkan bahwa pendidikan anak usia dini adalah suatu upaya pembinaan yang ditujukan kepada anak sejak lahir sampai dengan usia enam tahun yang dilakukan melalui pemberian rangsangan pendidikan untuk membantu pertumbuhan dan perkembangan jasmani dan rohani agar anak memiliki kesiapan dalam memasuki pendidikan lebih lanjut. ${ }^{12}$

Pendidikan anak usia dini bisa juga dikatakan sebagai suatu proses pembinaan tumbuh kembang anak usia lahir hingga enam tahun secara menyeluruh, yang mencukup aspek fisik dan non fisik, dengan memberikan rangsangan bagi perkembangan jasmani, rohani (moral dan spiritual), motorik, akal pikir, emosional, dan sosial yang tepat agar anak dapat tumbuh dan berkembang secara optimal. ${ }^{13}$

Menurut Lydia Freyani Hawadi pendidikan anak usia dini merupakan tingkat pencapaian perkembangan yang memuat aktualisasi potensi yang dimiliki setiap anak melalui tahapan-tahapan perkembangan bukan tahapan pada akademiknya ${ }^{14}$.

Berdasarkan penjelasan para ahli dapat disimpulkan, pendidikan anak usia dini adalah suatu upaya pembinaan yang ditujukan kepada anak sejak lahir sampai dengan usia enam tahun untuk merangsang dan mengembangkan potensi-potensi yang telah dimiliki anak sehingga dapat beradaptasi dan bersosialisasi dengan lingkungannya.

\section{Pendidikan Karakter Anak Usia Dini}

Pendidikan karakter, pada tingkat institusi mengarah pada pembentukan budaya sekolah, yaitu nilai-nilai yang melandasi perilaku, tradisi, kebiasaan keseharian, dan simbol-simbol yang dipraktikan oleh semua warga sekolah dan masyarakat sekitar. Budaya sekolah merupakan ciri khas, karakter atau watak, dan meningkatkan citra sekoah tersebut dimata masyarakat luas. Tujuan pendidikan karakter ini akan berdampak langsung pada prestasi anak didik.

Menurut Ratna Megawangi, pendidikan karakter terhadap anak sebaiknya disesuaikan dengan fase usianya, yaitu:

1. Fase usia 0-3 tahun. Pada fase ini, peran orang tua sangat penting karena landasan moral baru dibentuk pada usia ini.

2. Fase usia 2-3 tahun. Pada fase ini anak sebaiknya sudah diperkenalkan pada sopan santun, serta perbuatan baik dan buruk.

3. Fase 0 (usia 4 tahun). Pada fase ini anak mengalami fase egosentris, dimana ia senang melanggar aturan, memamerkan diri, dan memaksakan keinginannya. Namun anak mudah didorong untuk berbuat baik, karena ia mengharapkan hadiah (pujian), dan menghindari hukuman.

4. Fase 1 (umur 4,5 - 6 tahun). Pada fase ini anak-anak lebih penurut dan bisa diajak kerja sama, agar terhindar dari hukuman orang tua.

5. Fase 2 (usia 6,5 - 8 tahun). Pada fase ini, anak merasa memiliki hak sebagaimana orang dewasa. Tidak lagi berpikir bahwa orang dewasa bisa

\footnotetext{
${ }^{12}$ Isjoni, M.Si., Ph.D., Model Pembelajaran Anak Usia Dini, (Bandung:Alfabeta 2009), hal.37.

${ }^{13}$ Mansur, M.A, Pendidikan Anak Usia Dini dalam Islam, (Jogjakarta: Pustaka Pelajar 2014), cet ke 5 hal.88.

${ }^{14}$ Lydia Freyani Hawadi, Prof.,Dr. Bahan Ajar Strategi Pembelajaran Anak Usia Dini, (Kementerian Pendidikan dan Kebudayaan, 2013), hal. 7
} 
memerintah anak-anak dan mempunyai potensi bertindak kasar akibat menurunnya otoritas orang tua atau guru. ${ }^{15}$

\section{METODE PENELITIAN}

Penelitian yang digunakan adalah penelitian kualitatif. Penelitian kualitatif adalah suatu strategi yang menekankan pada pencarian makna, pengertian konsep, karakteristik, gejala, symbol, deskripsi tentang suatu fenomena, fokus dan multimode, bersifat alami dan holistik, yang mengutamakan kualitas, menggunakan beberapa cara, serta disajikan secara naratif. ${ }^{16}$ Subjek dan objek penelitian adalah peserta didik TK B berjumlah 22 orang terdiri dari 12 anak lakilaki dan 10 anak perempuan.

Teknik pengumpulan data menggunakan observasi, wawancara dan studi dokumentasi. Sedangkan proses analisis data menggunakan teori Miles dan Hubermen, yang terdiri dari aktifitas reduksi data, penyajian data dan penarikan kesimpulan.

\section{HASIL PENELITIAN}

\section{Implementasi Pendidikan Karakter di RA Nurul Ikhlas}

Pelaksanaan pendidikan karakter dilakukan melalui kegiatan terprogram, pembiasaan dan keteladanan. Kegiatan terprogram dilakukan di dalam kelas, sedangkan kegiatan pembiasaan dilakukan di lingkungan sekolah dan di rumah. Pendekatan pembelajaran menggunakan sistem pembelajaran: "learning by playing", terintegrasi dengan pendidikan agama, serta mengenalkan sembilan pilar karakter dalam kurikulmnya" melalui pendekatan Beyond Centers and Circle Times (BCCT) atau sentra dan saat lingkaran.

Sentra main adalah area main anak yang dilengkapi dengan seperangkat alat main yang berfungsi sebagai pijakan yang diperlukan anak untuk mendukung perkembangan anak dalam tiga jenis permainan, yaitu main sensorimotor, main peran, dan main pembangunan. Sedangkan lingkaran merupakan saat guru duduk bersama anak dengan posisi melingkar untuk memberikan pijakan (arahan) kepada anak sebelum dan sesudah main.

Prinsip dasar dari pencapaian pembelajarannya adalah sekolah rumah bagi anak, guru adalah orang tua bagi anak di sekolah, dan anak itu unik. Oleh karena itu pelayanan pendidikan disesuaikan dengan kebutuhan individu anak. Pendidikan karakter pada anak usia dini di RA Nurul Ikhlas dilaksanakan secara terintegrasi dalam pembelajaran yang dilakukan secara menyeluruh dan sesuai dengan prinsip pengembangan anak secara bertahap sesuai DAP (Develop-mentally Appropriate Practice). Terintegrasi di sini artinya pendidikan karakter tidak berdiri sendiri ataupun terpisah dengan pembelajaran yang ada. Akan tetapi menyatu dengan pembelajaran di sekolah, dan dalam pembelajaran guru selalu memasukkan nilainilai karakter.

Kegiatan pembelajaran dibagi menjadi 4 (empat) yaitu: pembukaan, inti, istirahat, pengulangan kembali apa yang telah di ajarkan (recalling) dan di lengkapi dengan kegiatan evaluasi tentang apa yang telah dicapai peserta didik. Kegiatan dalam proses pembelajaran mencakup:

\footnotetext{
${ }^{15}$ Agus Wibowo, M.Pd, Pendidikan Karakter usia Dini:Strategi Membangun diusia Ema), (Jogjakarta, Pustaka Pelajar 2012), hal 88

${ }^{16}$ A. Muri Yusuf, Prof.,Dr., Metode Penelitian Kuantitatif, Kualitatif, dan Penelitian Gabungan (Jakarta: Pranada Media 2014), hal. 329.
} 


\section{a. Materi pembelajaran}

Di RA Nurul Ikhlas menggunakan pembelajaran "belajar dengan bermain", integrasi dengan pendidikan agama, serta mengenalkan sembilan pilar karakter" melalui pendekatan Beyond Centers and Circle Times (BCCT) atau sentra dan saat lingkaran. Materi pembelajarannya mencakup enam aspek perkembangan dan nilai moral agama ataupun nilai-nilai karakter, yang dituangkan melalui semua kegiatan yang dilakukan anak didik, yang meliputi cinta kepada Tuhan dan alam semesta, tanggung jawab, disiplin, mandiri, kasih sayang dan peduli, serta kerjasama.

Cinta kepada Tuhan dan alam semesta dituangkan kedalam materi pembelajaran berupa praktek sholat, terbiasa berdoa sebelum dan sesudah kegiatan, sayang kepada hewan dan tanaman serta lingkungan sekitar, serta menjaga kebersihan dan kesehatan diri. Tanggung jawab, disiplin dan mandiri dilakukan dalam kegiatan pembiasaan, anak dibiasakan agar menjadi pribadi yang bertanggungjawab dan mandiri dalam setiap kegiatan sehari-hari dengan cara datang kesekolah tepat waktu, berpakaian rapi, meletakkan sepatu dan tas pada tempatnya, menyimpan perlengkapan belajar setelah digunakan. Kasih sayang, peduli dan kerja sama dituangkan dengan kegiatan berbagi makanan atau bergantian mainan dengan teman, mendengarkan saat guru atau teman berbicara, serta dapat bekerja sama dengan teman.

\section{b. Metode pembelajaran}

Ada beberapa metode yang digunakan dalam pelaksanaan pendidikan karakter, yaitu:

1) Metode keteladanan

Keteladan adalah metode yang paling dekat dengan pembelajaran dan karakteristik anak usia dini. Melalui keteladanan guru, anak akan mudah menyerap apa yang mereka dengar, lihat dan rasakan dari guru, orang lain, dan lingkungan sekitar. Metode keteladan bagi anak usia dini lebih ke arah bagaimana guru dapat memberi contoh yang dapat dilihat anak. karena

2) Metode Pembiasaan

Metode pembiasaan yang digunakan dalam pendidikan karakter sama halnya dengan metode keteladanan karena pembiasaan itu lebih membekas pada diri anak dan akan terus dilakukan dalam kehidupan sehari-hari. Pembiasaan dilakukan pada semua kegiatan baik itu kegiatan yang terjadwal ataupun yang tidak, baik di dalam kelas maupun di luar kelas.

3) Metode bercerita

Metode bercerita biasanya digunakan pada sesi pagi yaitu saat pembahasan pilar, biasanya guru menggunakan buku pilar yang telah disediakan sekolah.

Selain itu membaca juga menjadi program rutin di RA Nurul Ikhlas, karena setiap akhir pembelajaran sebelum recalling guru selalu membacakan buku cerita, kali ini tidak menggunakan buku pilar namun tetap mengambil karakter-karakter baik yang akan disampaikan pada anak dengan tujuan cerita tersebut akan diingat dan ikuti anak.

4) Metode karyawisata

Metode karyawisata digunakan untuk menambah wawasan anak secara langsung karena anak belajar langsung di tempatnya. Disamping itu, 
melalui karya wisata guru juga dapat mengajarkan nilai-nilai karakter berdoa sebelum berangkat, disiplin saat berbaris sebelum berangkat, sopan ketika di tempat tujuan, mandiri, dapat bekerja sama, membuang sampah pada tempatnya, dan sebagainya.

\section{c. Pelaksanaan pembelajaran}

Pelaksanaan pendidikan karakter di RA Nurul Ikhlas dilakukan dengan kegiatan pembiasaan dan keteladanan. Kegiatan belajar mengajar di RA Nurul Ikhlas dilakukan sejak pukul 07.15 WIB sampai dengan pukul 11.30 WIB. Kegiatan dimulai dengan penyambutan anak di depan pintu gerbang. Lalu anak-anak diminta untuk meletakkan sepatu di tempat sepatu dan menyimpan tas di tempatnya. Setelah itu anak membaca iqro secara individu dengan guru kelompok masing-masing. Pada pukul 07.30 anak-anak berkumpul untuk berbaris dan ikrar. Setelah itu anak-anak melakukan kegiatan yang disebut grossmotor, kegiatan ini bertujuan untuk menyalurkan energi anak-anak agar didalam kelas lebih kondusif dan konsentrasi mengikuti kegiatan belajar mengajar.

Jam 08.00 anak-anak masuk ke dalam kelas. Dalam kegiatan dikelas anak membaca do'a sebelum belajar, hapalan surat pendek, hadits dan doa sehari-hari. Setelah itu dilanjutkan dengan absensi dan jurnal, jurnal sendiri diisi dengan menggambar bebas. Biasanya anak-anak diminta menggambar tentang perasaannya pada hari itu atau mengerjakan lembar kerja yang telah disediakan. Dan pada pukul 09.00 WIB di lanjutkan dengan pemberian materi pilar-pilar karakter, media yang di gunakan saat menjelaskan pilar dengan buku pilar atau boneka tangan. Dan pada pukul 09.15 WIB sampai 09.30 pembahasan tema dan pembelajaran.

Berikut ini adalah bentuk-bentuk kegiatan pembiasaan yang dilakukan sebagaimana tabel 1:

\section{Tabel 1}

Bentuk kegiatan pembiasaan di RA Nurul Ikhlas

\begin{tabular}{|c|c|c|c|}
\hline No & Indikator & Sub indikator & Bentuk kegiatan \\
\hline 1 & $\begin{array}{l}\text { Cinta } \\
\text { Kepada } \\
\text { Tuhan } \\
\text { dan Alam } \\
\text { Semesta }\end{array}$ & $\begin{array}{l}\text { a. Mengetahui agama yang } \\
\text { dianutnya } \\
\text { b. Mengenal ciptaan Allah } \\
\text { c. Berdoa sebelum dan } \\
\text { sesudah kegiatan } \\
\text { d. Memberi dan menjawab } \\
\text { salam } \\
\text { e. Menjaga kebersihan diri } \\
\text { dan lingkungan }\end{array}$ & $\begin{array}{l}\text { a. Praktek sholat dan mengaji } \\
\text { b. Sayang kepada binatang dan } \\
\text { tanaman yang ada di sekitarnya } \\
\text { c. Terbiasa berdoa sebelum dan } \\
\text { sesudah kegiatan } \\
\text { d. Mengucapkan dan menjawab salam } \\
\text { e. Mencuci tangan dan membuang } \\
\text { sampah pada tempatnya }\end{array}$ \\
\hline 2 & $\begin{array}{l}\text { Tanggung } \\
\text { jawab, } \\
\text { disiplin, } \\
\text { dan } \\
\text { mandiri }\end{array}$ & $\begin{array}{l}\text { a. Menyimpan perlengkapan } \\
\text { belajar setelah digunakan } \\
\text { b. Mengikuti peraturan } \\
\text { disekolah } \\
\text { c. Datang kesekolah tepat } \\
\text { waktu } \\
\text { d. Melepas dan memakai } \\
\text { sepatu sendiri } \\
\text { e. Membawa dan menyimpan } \\
\text { tas ditempatnya } \\
\end{array}$ & $\begin{array}{l}\text { a. Merapikan mainan setelah } \\
\text { digunakan } \\
\text { b. Memakai seragam sekolah dengan } \\
\text { rapih } \\
\text { c. Datang kesekolah tepat waktu } \\
\text { d. Meletakkan sepatu pada tempatnya } \\
\text { e. Meletakkan tas pada tempatnya }\end{array}$ \\
\hline 3 & $\begin{array}{l}\text { Kasih } \\
\text { sayang, }\end{array}$ & $\begin{array}{l}\text { a. Dapat memberi dan } \\
\text { menolong }\end{array}$ & $\begin{array}{l}\text { a. Membantu teman yang kesulitan } \\
\text { b. Berbagi makanan atau }\end{array}$ \\
\hline
\end{tabular}




\begin{tabular}{|c|c|c|c|}
\hline No & Indikator & Sub indikator & Bentuk kegiatan \\
\hline & $\begin{array}{l}\text { peduli, } \\
\text { dan } \\
\text { kerjasama }\end{array}$ & $\begin{array}{l}\text { b. Senang berbagi dengan } \\
\text { teman } \\
\text { c. Mau mendengarkan saat } \\
\text { orang lain bicara } \\
\text { d. Dapat bekerjasama dalam } \\
\text { satu tim }\end{array}$ & $\begin{array}{l}\text { meminjamkan alat main dengan } \\
\text { teman } \\
\text { c. Mendengarkan saat teman atau } \\
\text { guru berbicara } \\
\text { d. Dapat bermain dan mengerjakan } \\
\text { tugas bersama teman }\end{array}$ \\
\hline
\end{tabular}

Pelaksanaan kegiatan pembiasaan yang dilakukan dengan cara:

1) Guru melakukan dialog ataupun bercerita sederhana dengan anak untuk menggali pengetahuan dan pemahaman anak. Misalnya pada saat itu ada salah satu anak yang kesulitan membuka tempat minum, maka guru menstimulus dengan mengatakan: apakah ada yang mau membantu Fabian? lalu ketika ada anak yang mau membantu, guru bisa memberi apresiasi berupa pujian bahwa anak tersebut memiliki karakter suka menolong, dan menjelaskan siapa yang suka menolong serta membantu orang yang sedang kesulitan akan memiliki banyak teman dan mendapatkan pahala dari Allah.

2) Guru membangun penghayatan dengan anak. Setelah cerita dan dialog yang dilakukan maka selanjutnya guru mengajak anak diskusi ringan untuk mengetahui lebih lanjut tingkat pemahaman anak. Misalnya: bagaimana kalau teman-teman sedang kesulitan tapi tidak ada yang mau menolong, pasti rasanya sedih sekali. Setelah itu guru masuk pada materi pilar yang akan dibahas pada hari itu, biasanya guru menggunakan buku pilar yang sudah disediakan sekolah. Guru mengajak anak melakukan nilai-nilai yang sudah diceritakan. Setelah guru menggali lebih lanjut terkait pengetahuan dan pemahaman anak maka selanjutnya guru mengajak anak memberikan contoh dengan menanyakan: siapa yang dapat memberikan contoh sikap baik seperti apa. Lalu satu persatu anak diminta untuk memberikan contoh dan menanamkan agar melakukan perbuatan tersebut.

Sedangkan bentuk kegiatan keteladanan yang dilakukan pendidik, diantaranya mencontohkan sikap berdoa yang baik, berpakaian rapi dan sopan, datang ke sekolah tepat waktu, berbicara lembut dan sopan serta menjadi pendengar yang baik dan menjaga lingkungan dengan membuang sampah pada tempatnya,

\section{d. Evaluasi pembelajaran}

Evaluasi pembelajaran mengacu pada RPPH hari tersebut dan pengamatan guru terhadap perilaku peserta didik baik saat pembelajaran berlangsung maupun setelah selesai pembelajaran. Bentuk evaluasi yang digunakan, pertama acting feeling, yaitu drama yang dilakukan oleh guru di depan anak didik tanpa sepengetahuan mereka, drama itu sendiri berisikan tentang nilai karakter yang sedang diajarkan namun yang bertentangan. Kedua, pada hari yang sama anak-anak diberikan kuesioner yang akan diisi oleh orang tua, apakah karakter yang sudah diajarkan di sekolah muncul di rumah atau tidak, kuesioner ini bisa digunakan guru sebagai acuan penilaian lanjutan yang akan diberikan pada akhir semester dengan format penilaian dan indikator yang sudah disusun. 


\section{Faktor Pendukung dan Penghambat Implementasi Pendidikan Karakter}

Hasil penelitian ditemukan faktor-faktor pendukung implementasi pendidikan karakter, yaitu: a. adanya RPPH yang terintegrasi dengan nilai-nilai karakter yang dilakukan dengan metode dan media yang bervariasi sesuai dengan tema atau sub tema yang akan diajarkan, b. Adanya peraturan, c. Kesabaran dan keteladanan guru, dan d) Dukungan sekolah dengan mengikutsertakan guru mengikuti pelatihan tentang pendidikan karakter.

Sedangkan faktor-faktor penghambatnya, yaitu: a. Keselarasan penguatan nilai-nilai karakter di sekolah dan di rumah yang belum optimal. Karakter baik yang telah ditanamankan disekolah tidak distimulus lagi oleh orang tua dirumah, sehingga karakter baik tersebut hanya terjadi disekolah dan belum menjadi kebiasaan, b. Lingkungan, perilaku dan perkataan yang kurang baik sering kali diperoleh anak di luar sekolah sehingga karaker baik belum menjadi kebiasaan., dan c. Penggunaan gadget, televisi dan internet yang tidak terkontrol atau tanpa edukasi dari orang tua dapat mempengaruhi perilaku anak.

\section{KESIMPULAN}

Berdasarkan hasil penelitian, maka dapat disimpulkan sebagai berikut:

1. Implementasi pendidikan karakter di RA Nurul Ikhlas:

a. Pelaksanaan pendidikan karakter dilakukan melalui kegiatan terprogram, pembiasaan dan keteladanan. Pendekatan pembelajaran menggunakan sistem pembelajaran: "learning by playing", terintegrasi dengan pendidikan agama, serta mengenalkan sembilan pilar karakter dalam kurikulmnya" melalui pendekatan Beyond Centers and Circle Times (BCCT) atau sentra dan saat lingkaran. Metode pembelajaran yang digunakan yaitu keteladanan, pembiasaan, bercerita dan karyawisata.

b. Evaluasi pembelajaran mengacu pada RPPH hari tersebut dan pengamatan guru terhadap perilaku peserta baik saat pembelajaran berlangsung maupun setelah selesai. Bentuk evaluasi yang digunakan adalah acting feeling, dan kuesioner.

2. Faktor pendukung dan penghambat implementasi pendidikan karakter

a. Faktor-faktor pendukung implementasi pendidikan karakter, yaitu: a. adanya RPPH yang terintegrasi dengan nilai-nilai karakter, b. kesabaran dan keteladanan guru, dan c) Dukungan sekolah dengan mengikutsertakan guru mengikuti pelatihan tentang pendidikan karakter.

b. Faktor-faktor penghambatnya, yaitu: a. Keselarasan penguatan nilai-nilai karakter di sekolah dan di rumah yang belum optimal. b. Lingkungan, yang kurang kondusif c. Penggunaan gadget, televisi dan internet yang tidak terkontrol atau tanpa edukasi yang optimal.

\section{DAFTAR PUSTAKA}

Arifin, M dan Barnawi, 2012. Strategi dan Kebijakan Pendidikan Karakter. Jogjakarta :Ar-Ruzz Media.

Aunillah, Nurla Isna, 2011. Pnduan Menerapkan Pendidikan Karakter diSekolah, Jogjakarta : Laksana

Basrowi dan Suwandi, 2008. Memahami Penelitian Kualitatif. Jakarta :PT RinekaCipta.

Fadillah, Muhammad dan Lilif Mualifatu Khorida, 2013. Pendidikan Karakter Anak Usia Dini Jogjakarta : Ar-Ruzz Media. 
Gamma, Abla Bassat, 2006. Mendidik Mentalitas Anak Panduan Bagi Orang TuaUntuk Menumbuhkan Mentalitas Luar Biasa Pada Anak-anaknya. Sukoharjo Samudera.

Hawadi, Freyani, 2013. Bahan Ajar Strategi Pembelajaran Anak Usia Dini : Kementerian Pendidikan dan Kebudayaan.

Herdini, Adelia, 2016. "Implementasi Pendidikan Karakter Anak Usia Dini (studi kasus dari di Kelompok Bermain Pelangi Bangsa Pemalang)" Skripsi. Pemalang: Universitas Negeri Semarang.

Hurlock, E.B., 2018. Child Development. Inggris : Erlangga.

Isjoni. 2009. Model Pembelajaran Anak Usia Dini. Bandung : Alfabeta.

Kementrian Pendidikan Nasional, 2011. Panduan Pelaksanaan Pendidikan Karakter, Pusat Kurikulum dan Perbukuan

Kesuma, dkk., 2013. Pendidikan Karakter Kajian Teori dan Praktik di Sekolah, Bandung : PT RemajaRosdakarya.

Koesoema, Doni, 2007. Pendidikan Karakter Strategi Mendidik Anak di Zaman Global. Jakarta. : Grasindo.

Kurniasih, dkk., 2017. Pendidikan Karakter Internalisasi dan Metode Pembelajaran di sekolah. Kata Pena.

Lydia, 2012. Konsep Dasar Kemendikbud :Kementerian Pendidikan dan Kebudayaan.

Mansur, 2014. Pendidikan Anak Usia Dini Dalam Islam. Jogjakarta : Pustaka Pelajar

Megawangi, Ratna., 2016. Pendidikan Karakter Solusi yang Tepat Untuk Membangun Bangsa. Depok : Indonesia Haritage Foundation.

Megawangi, dkk., 2005. Pendidikan yang Patut dan Menyenangkan. Depok : Indonesia Haritage Foundation

Munandar, Utami., 2014. Pengembangan Kreativitas Anak Berbakat: Rineka Cipta.

Musbikin, Imam., 2010. Buku Pintar PAUD (dalam perspektif islam). Jogjakarta : Laksana

Satori, Djam'an dan Aan Komariah, 2012. Metodelogi Penelitian Kualitatif, Bandung :Alfabeta

Sugiyono, 2014. Metode Penelitian Kuantitatif, Kualitatif, dan R\&D. Bandung: Alfabeta

Sulistiorini, dkk.,. 2012. Pendidikan Karakter Anak Usia Dini. Malang : Universitas Negeri Malang

Wibowo, Agus., 2012. Pendidikan Karakter Usia Dini, Jogjakarta : Pustaka Pelajar

Wiyani, Novan Ardi., 2018. Pendidikan Karakter Berbasis Total Quality Management. Jogjakarta : Ar-Ruzz Media.

Yaumi, Muhammad, 2014. Pendidikan Karakter: Landasan, Pilar, dan Implementasi.Jakarta : Prenadamedia Group

Yusuf, A Muri, 2014. Metode Penelitian Kuantitatif, Kualitatif, dan Penelitian Gabungan, Jakarta : Pranada Media 